\title{
Aquaculture Carrying Capacity and Water Quality in Indonesian Lakes and Reservoirs - A New Project
}

\author{
David A. Bengtson \\ Department of Fisheries, Animal and Veterinary Sciences, University of Rhode Island, Kingston, Rhode Island 02881, USA \\ Email: bengtson@uri.edu
}

\begin{abstract}
David A. Bengtson. 2014. Aquaculture Carrying Capacity and Water Quality in Indonesian Lakes and Reservoirs - A New Project. Aquacultura Indonesiana, 15 (2) : 46-50. Aquaculture is growing rapidly in Southeast Asia (SEA) and five of the top ten aquaculture producers in the world are countries in SEA. The need to manage aquaculture responsibly is critical. Calculation of aquaculture carrying capacity (ACC) for shared water bodies is necessary for proper management. I review my observations of the needs and capabilities of SEA governments for ACC and then describe a new project in which teams of U.S., U.K. and Indonesian scientists will work on ACC for three Indonesian water bodies - Lake Cirata, Lake Toba and Lake Jatigede.
\end{abstract}

Keywords: Carrying capacity; Cirata; Jatigede; Modeling; Toba

\section{Introduction}

Aquaculture can impact the environment in many ways, including habitat destruction, organic enrichment, introductions and transfers of species, harvesting of small pelagic fish from the ocean for fish meal, and so on. Organic enrichment of the environment is a major concern; that is, the feed provided to fish in cages that ends up as uneaten feed on the bottom, fish feces from undigested feed, and the ammonia that is excreted as a waste product by fish after they feed.

A healthy environment provides ecosystem services, such as primary production by plants, nitrification (transformation of ammonia to nitrate) by bacteria, and decomposition (breakdown of dead organic material) by other bacteria. These processes allow ecosystems to remain in balance. When an industry like aquaculture organically overenriches an ecosystem, the normal ecosystem services are overwhelmed, leading to an unbalanced, and possibly destroyed, ecosystem. We can broadly define aquaculture carrying capacity (ACC) as the ability of the ecosystem to accommodate aquaculture, but more specific carrying capacities (CC) have also been defined (McKindsey et al., 2006). Physical CC is simply the maximum amount of aquaculture that can physically fit in a water body. Production CC is the maximum amount that does not cause unacceptable impacts to the farms themselves. Ecological CC is the maximum amount that does not cause unacceptable impacts to the ecosystem.
Social CC is the maximum amount that does not cause unacceptable impacts to human society.

Aquaculture and ecosystems have each been the subject of modeling efforts for many years. A model is simply a representation of the relationships among variables and can range from very simple to very complex. Many types of models have been developed for aquaculture activities: bioenergetic models for aquaculture production; models of pond ecosystem structure and function; benthic deposition models for organic wastes; water quality models for distribution of dissolved oxygen in water bodies, etc. Many of these models can be used to select optimal sites for an aquaculture operation or to place limits on aquaculture production in a water body. A basic paradigm in aquaculture development is modeling for decision-making, followed by monitoring to see how accurate the model predictions were and to correct the aquaculture operations in the face of inaccurate predictions.

\section{Assessment of ACC needs and capabilities in Southeast Asia}

Aquaculture is expanding rapidly in SE Asia and there is great potential to exceed ACC in many places. Several examples of ecosystems abused by aquaculture already exist. The U.S. Soybean Export Council (USSEC) wants to see stable development of the aquaculture industry in the region as a market for soy-based aquaculture feeds. In 2012, the U.S. soy industry contracted me via its United Soybean Board (USB) to lead an effort in "Modeling of Common Water 
Bodies" in SE Asia. I visited regulators, as well as aquaculture sites, in Indonesia, Philippines, Thailand, and Vietnam to assess the needs and capabilities of these countries for modeling of aquaculture's impacts on ecosystems. In 2013, I added Malaysia and Myanmar to the list and also received additional funding from the U.S. Agency for International Development (U.S. AID) for similar work in Cambodia.

My main findings in 2012 were: 1) countries would like to have and use models for lakes/reservoirs, rivers, and bays/estuaries, 2) limited modeling capability seems to exist, at least in agencies responsible for aquaculture, 3) data to put into the models are quite limited, and 4) there is uncertainty or disagreement within countries about what to protect, farmers only or whole ecosystems (i.e., production $\mathrm{CC}$ or ecological CC). Additional findings in 2012 were that 1) exceeding ACC in many places makes the industry very inefficient due to high levels of disease or mortality (thus, I believe farmers could change their practices based on economic reasons, not just ecological ones), 2) whatever national regulators think, permits are distributed at the local level (so we need an effort to educate farmers and local officials about these overcapacity issues), and 3) all countries have similar problems.

\section{Indonesian $\mathrm{ACC}$ - a new project}

In late 2013, responding to a Request for Proposals (RFP) for the joint U.S.-U.K Global Innovation Initiative (GII) program. Working with partners at the University of Stirling in the U.K., and Institut Pertanian Bogor (IPB) and Surya University in Indonesia, the University of Rhode Island (URI) submitted a successful proposal, outlined below, for work to be conducted in Indonesia from 2014 to 2016 . We would like the participants at the $4^{\text {th }}$ International Conference on Aquaculture Indonesia to know about our new project. Our vision is to bring together leading aquaculture scientists from the U.S., the U.K. and Indonesia to conduct teaching, research, and outreach in support of sustainable development of Indonesia's aquaculture industry. This effort addresses the topic area "Agriculture, Food Security and Water" identified in the RFP.

Aquaculture is the world's fastestgrowing form of agriculture, with growth rates averaging $8.8 \%$ annually from 1980 to 2010 (FAO, 2012). World aquaculture production in 2010 (excluding plants and non-food products) reached 60 million metric tons, approximately equivalent to the amount of seafood for human consumption coming from all the world's wildcapture fisheries (FAO, 2012). In many developing countries, especially in Southeast Asia, seafood is a major source of protein. As wild-capture fishery production has reached its limit globally, aquaculture will be increasingly called upon to meet the protein needs of the world's population. Per-capita seafood consumption in Indonesia in 2012 was $33 \mathrm{~kg}$ (http://www.thejakartaglobe.com/news/jakarta/gr oup-breaks-record-to-show-pride-of-indonesia-

rich-fish-resources/), approximately 6.5 times the per-capita chicken consumption; although Indonesian wild-capture fishery production increased at only $2 \%$ per year from 2003-2009, aquaculture production increased $13 \%$ annually (http://www.efeedlink.com/contents/04-112012/21e95b03-6863-495b-b881-a566cc673d24a181.html). By contrast annual per capita seafood consumption in the U.S. is approximately $7.4 \mathrm{~kg}$ and in the U.K. approximately $9.4 \mathrm{~kg}$.

With the expansion of aquaculture in both fresh and salt waters of Southeast Asia to meet the growing demand for fish, some water bodies have already exceeded their abilities to assimilate the wastes from aquaculture production. Wastes include benthic deposition of uneaten feed and feces, as well as eutrophication from ammonia produced by the fish. The need to determine the maximum amount of aquaculture that can take place in a given water body is great. As wastes increase, water quality declines, which can lead to increases in fish disease and mortality. For instance, Rice and DeVera (1998) described widespread fish kills associated with intensive net pen culture of milkfish in the estuaries near Dagupan City in the Philippines in 1996 following prior fish kills a few years earlier associated with fish pens in the freshwater Laguna de Bay near to Manila. Since that time, the incidence of fish kills has become more frequent and has become problematic throughout Southeast Asia, including Indonesia.

As mentioned above, McKindsey et al. (2006) identified four types of aquaculture carrying capacity: physical, production, ecological and social. Resource managers first need to decide what they want to protect (farmers, ecosystem, society), then try to calculate the appropriate carrying capacity. A variety of models can be used to predict the impacts of aquaculture wastes in the 
environment: benthic deposition models, water quality models, full ecosystem models, simple mass-balance models, etc. Use of each depends on needs, available data, and expertise of the user. Ideally, such models are used before aquaculture production begins, in order to allow regulators to only permit the appropriate amount of aquaculture and/or to properly site the aquaculture operations.

The vision for this project is that we will effect curriculum development, research capability, and outreach/extension capability in the two Indonesian universities and the country as a whole. This effort will also enhance the teaching capabilities and scholarly productivity of the participants at the U.S. and U.K. partner universities.

\section{Project Activities}

Our project activities are based on discussions among the participating institutions and Mr. Maskur, Director, Directorate of Fish Health and Environment, Directorate General of Aquaculture, Ministry of Marine Affairs and Fisheries, Republic of Indonesia. A great deal of Indonesian aquaculture for domestic consumption occurs in large lakes and reservoirs. In some cases, aquaculture has expanded so quickly in those water bodies, without effective regulation or prior estimation of aquaculture carrying capacity, that the water quality has deteriorated badly and fish kills are not uncommon. A relatively simple way to estimate aquaculture carrying capacity in data-poor freshwater lakes and reservoirs is by massbalance modeling of nitrogen $(\mathrm{N})$ and phosphorus $(\mathrm{P})$. Briefly, knowing the volume of the water body, inputs and outputs of water through the system, and background levels of $\mathrm{N}$ and $\mathrm{P}$ in the system, as well as information about the $\mathrm{N}$ and $\mathrm{P}$ content of the aquaculture feed and the feed conversion ratio (FCR) of feed to fish tissue in the (actual or proposed) aquaculture operation, one can determine the amount of waste $\mathrm{N}$ and $\mathrm{P}$ that aquaculture will add to the system per $\mathrm{kg}$ of fish produced. Based on desired water quality standards, which may vary (e.g., with goals of protecting drinking water, water quality for the aquaculture itself, etc.), one can then calculate the maximum amount of aquaculture that can be safely permitted.

Several ways exist to mitigate the environmental impacts of finfish aquaculture in cages in lake/reservoir systems. These include, but are not limited to: a) improving diet quality and FCR so that less excess $\mathrm{N}$ and $\mathrm{P}$ enter the environment, b) removing uneaten feed and fish feces that fall through the cages, and c) adding rafts with commercially important plants (e.g., lettuce, cabbage, etc.) around the cages to take up the excess $\mathrm{N}$ and $\mathrm{P}$ as nutrients. Integrated aquaculture/agriculture of fish and plants represents a path toward long-term sustainability of aquaculture.

Indonesia contains large lakes and manmade reservoirs that span the spectrum of eutrophication due to aquaculture. We propose to work with three of those water bodies. Lake Cirata is a reservoir in West Java, dammed for hydropower, in which aquaculture was begun as a means of employment for farmers displaced by the flooding of their land. Unchecked expansion has meant that 50,000 fish cages now occupy the reservoir, badly deteriorating water quality and periodically leading to fish kills. Lake Toba is a natural lake in northern Sumatra, in which carp aquaculture began decades ago. In recent years, tilapia aquaculture has taken over, engaging both large companies and small farmers, competing for space with tourism, and eutrophying the water. Lake Jatigede is a new, man-made lake in West Java (also built for hydropower) that currently lacks aquaculture. Because of the environmental damage due to aquaculture previously seen in Lake Cirata and similar reservoirs in West Java, the government is trying to decide whether and how to permit aquaculture development in Lake Jatigede. At the same time, the government is considering options for limiting future aquaculture development in Lake Toba. Finally, a private company is proposing to suction organic wastes from aquaculture from the bottom of Lake Cirata for use as agricultural fertilizer.

We propose to engage teams of U.S., U.K. and Indonesian students in mass-balance modeling of the three aforementioned lakes. In particular, we propose to model $\mathrm{N}$ and $\mathrm{P}$ under conditions of a) aquaculture alone, with no mitigation, b) aquaculture with modifications only to feed and feeding practices, c) aquaculture with co-production of plants to take up excess nutrients, d) aquaculture with removal of sludge from the lake bottom, and e) all combinations of $\mathrm{b}, \mathrm{c}$, and d above. Results of our efforts will help inform the government's decision-making and allow them to consider alternative scenarios to simply permitting aquaculture without mitigation. 
Our goal is to create three teams of students, each team consisting of one student from each institution, to work on the three lakes (i.e., one lake per team). We also envision that a total of nine faculty members from the four institutions will be involved, so that each student team will have a team of three faculty members working with it on its particular lake. Each lake's team (students and faculty) will visit the lake, meet with local officials and fish farmers (actual in the cases of Lakes Cirata and Toba, potential in the case of Lake Jatigede) to explain the project and to seek their input. They will then gather the data needed for the modeling, mostly from existing sources like government water quality analyses, but also from fish feed companies and the literature. Next, they will decide on specific scenarios to model, based on available data and feedback from local people (e.g, what specific plants to grow in association with aquaculture). They will then conduct the modeling exercises per se, determining for each lake the finfish aquaculture carrying capacity under the aforementioned scenarios of mitigation vs. no mitigation. Finally, the team will return to the lake, explaining to the local officials and farmers what they discovered via the modeling efforts. The will also report their results to the appropriate government officials.

\section{Work Plan/Time Frame}

Given the academic year schedules of the four institutions, we are conducting the on-site work in year 1 during June-July, 2014. Identification of students, as well as logistic arrangements, were made in the April to June period leading up to that. Three students from URI, along with Drs. David Bengtson and Michael Rice, three students from Stirling, along with Drs. Francis Murray, and three students from Surya University, along with Ms. Cut Desyana, traveled to IPB to initiate the project with three IPB students led by Dr. Mohammad Mukhlis Kamal. We spent the past week in intensive training sessions with the faculty from the four institutions, learning specific aspects of the mass-balance modeling, as well as appropriate methods for interacting with local officials and fish farmers. During the week, we formed the three teams and discussed within each team the specific aspects of their particular lake that they will need to consider as they proceed. During the next week, the teams will travel to their respective lakes and meet with the local officials and fish farmers, gathering information about the particular needs and cultural considerations of those constituents. Following that, they will spend a week back in Jakarta/Bogor constructing realistic scenarios that they can model for their particular lake and deciding how to divide up the required work.

After the 2014 on-site work, the U.S. and U.K. students and faculty members will return to their respective countries. During the 2014-2015 academic year, they will work closely via e-mail and Skype conversations with their Indonesian counterparts to accomplish the modeling required for the project. As the results become available, each team will work with Dr. Henry Njoo from Surya University, who is a specialist in agribusiness, and who will advise each group on potentials for profitable business development using the various modeled scenarios. In July, 2015, the U.S. and U.K. students and faculty members will return to Indonesia to present their findings to government officials at the national level, and to the local officials and fish farmers with whom they previously met.

During this project, the U.S. and U.K. faculty members will work with their Indonesian counterparts and government officials to identify projects (and sources of funding) to expand work on aquaculture carrying capacity in Indonesia and beyond. This is likely to include expansion to additional types of models (hydrodynamic models, benthic deposition models, et al.) for use in additional environments (e.g., coastal waters).

We anticipate that during the period of September, 2015, to March, 2016, the students involved in the project will be finalizing their results and writing their theses prior to graduation in May/June 2016. These theses will be in a form suitable for subsequent publication in peerreviewed journals, which will enhance the ability of students to obtain employment, as well as enhancing the academic careers of the faculty members involved.

\section{Measures of Partnership Sustainability}

We expect that the use of integrated research teams including faculty members and students from each of the four universities will enhance the likelihood of sustainable relationships. The expected outcomes and results of this project are a series of recommendations on aquaculture carrying capacity in the three lakes, provided to the Division of Fish Health and Environment, Directorate General of 
Aquaculture, Ministry of Marine Affairs and Fisheries. The results will also be written up as M.S./M.Sc. dissertations at URI, Stirling, and IPB (Surya does not yet have a graduate program), and ultimately will be submitted to peer-reviewed journals for publication as coauthored outputs. We anticipate that, with three graduate students per lake and four distinct modeling scenarios (plus combinations) each graduate student's thesis will consist of modeling at least one scenario. Peer-reviewed publications will be multi-authored and include all the modeling scenarios for a given lake in a single publication. The master's students produced by the respective universities will have a) specific knowledge of aquaculture carrying capacity issues and methods for calculation, which are desperately needed in Indonesia and throughout Southeast Asia, and b) experience working in a developing country (for US and UK students), especially working with members of a multinational team and interacting with the local population of stakeholders. The Surya undergraduate students will expand their research capabilities by working in these research teams with professors and graduate students and should be inspired to continue their education in graduate school. Students from Surya and IPB will be in demand for their abilities gained as a result of this project and could potentially start their own businesses to do this kind of work throughout the country as aquaculture is mandated to expand in a sustainable manner. In preparing the project, we chose to be very focused and specific in locating the work in freshwater bodies, given the funding and logistic constraints. Abundant opportunities exist to expand this work to other water bodies, most especially coastal waters, where Indonesian aquaculture has the greatest potential for expansion in the coming decades.

\section{References}

FAO (Food and Agriculture Organization). 2012. The State of World Fisheries and Aquaculture 2012. www.fao.org/docrep/016/i2727e/i2727e.pdf

McKindsey, C.W., H. Thetmeyer, T. Landry, and W. Silvert. 2006. Review of recent carrying capacity models for bivalve culture and recommendations for research and management. Aquaculture, 261:451-462.

Rice, M.A. and A.Z. DeVera. 1998. Aquaculture in Dagupan City, Philippines. World Aquaculture, 29 (1) : 18-24. 